\title{
Biden's Administration Policies towards the Middle East': Initial Appraisal and Potential Prospect
}

\author{
Hassan Hamdan AlAlkim ${ }^{1}$ \\ ${ }^{1}$ Professor of Political Science and President of the American University of Ras AlKhaimah-UAE \\ Correspondence: Hassan Hamdan AlAlkim, Professor of Political Science and President of the American University of \\ Ras AlKhaimah-UAE.
}

Received: December 14, 2021

Accepted: January 14, $2022 \quad$ Available online: January 21, 2022

doi:10.11114/ijsss.v10i2.5423

URL: https://doi.org/10.11114/ijsss.v10i2.5423

\begin{abstract}
In light of the challenges, difficulties, and risks facing the United States, and the inherited pitfalls at the local and global levels, this research aims to examine the credibility of Joe Biden's foreign policy campaign promises towards the region after one- year in office. The aim is to analyze the U.S. behavior towards the Middle East based on Hans Morgenthau's approach to the pursuance of the national interest at all cost. The hypothesis is that Biden's Administration will follow a permanent interest approach towards the Middle East which has been constant over long periods of time. The U.S. policy towards the Arab world has remained remarkably consistent across administrations ever since the discovery of the region's energy resources. This analysis suggests that the desire to shift U.S. foreign policy emphasis from the troubled Middle East to south Asia ${ }^{\text {ii }}$ is a persisting foreign policy objective under Biden. However, the new focus on Asia Pacific and de-prioritization of the Middle East in U.S. foreign policy does not negate the assumption that the region, due to its geopolitical importance, will continue to enjoy and attract significant U.S. attention. Joe Biden's Administration has been pragmatic in its approach towards the region abandoning the "American values" of democratization and human rights in pursuance of national interest.
\end{abstract}

Keywords: Biden, U.S., Foreign Policy ${ }^{\mathrm{iii}}$, National Interest ${ }^{\mathrm{iv}}$, Middle East, Peace Process, Diplomacy ${ }^{\mathrm{v}}$.

\section{Introduction}

The election of the Democratic candidate, Joseph Biden, as President of the United States of America on November $3^{\text {rd }}$, 2020 for a presidential term extending until 2024 opens an opportunity for the U.S. establishment to heal the domestic rift and review its foreign policy undertakings. Effective foreign policy requires a process of reconciling domestic and foreign imperatives. Foreign policy theorists like Hans Morgenthau contend that realism is the default position among leaders who exhibit prudence and willingness to balance risks and idealism. Liberals emphasize the overriding importance of interdependence, whereas cosmopolitans stress the "common humanity" of individuals and respect for other international institutions (Nye, 2020, pp. 39-41).

U.S. policy towards the Middle East "has remained remarkably consistent across administrations, with exception to the Trump's era, ever since the region's energy resources began to be exploited, and especially since the United States took on the mantle of global leadership" (Mezran and Varvelli, 2019, p. 15). The U.S. has sought to use arms sales to bolster partners' capabilities to advance major U.S. regional security interests including countering terrorism, ensuring an uninterrupted oil flow to the global market, security of Israel, and containing Iran (CRS R44984, Nov. 23, 2020, p. 4). Some see the organizing principle of Washington Middle East policy as having morphed into containing Iran regardless of the destabilizing effects of this policy on the region (Parsi, 2021, p. 3).

Although foreign policy makers operate within a set of rules, constraints and expectation (Robinson \& Snyder, 1965 , p. 448) they, according to Michel Brecher, act in accordance to their perception of reality (1974, p. 264). Therefore, Joe Biden is expected to pursue a foreign policy based on permanent interest model characterized by continuity across both Republican and Democratic administrations since the end of World War II up to 2016. Biden's selection of his team confirms the desire to go back to institutionalized diplomacy pursuing a collaborative approach to global issues, engaging close allies and partners on a range of mutually important issues. The aim of the study is to explore whether Joe Biden's national interest approach will be a "recycled" yet reinvigorated Obama-Biden foreign policy or will it be a more progressively engaged policy with emphasis on a Two-State solution for the Arab-Israeli conflict. The argument 
here is that the evidence to date suggests that Biden's interest-driven foreign policy is fundamentally a pragmatic not more than a tweak of the Obama-Biden approach, despite his emphasis on a Two- State solution for the conflict. The study will rely mainly on secondary sources, and the analysis will focus only on the Arab world and not cover the Iran nuclear deal (JCPOA) and the war in Yemen, as they have been covered in another study (AlAlkim, 2021, pp. 378-401). The paper will focus on the most important contemporary issues in the Middle East in relation to how the Biden Administration will elect to deal with the region. This study is significant in that it analyzes the Biden Administration's foreign policy agenda, in the first year, in dealing with the most prominent and critical issues affecting stability in the Middle East. It will discuss Biden's foreign policy in the context of the following issues: the turbulent Middle East region, peace agreements between Israel and Arab countries, challenges to resurrecting the Two-State solution, and Iran and the Middle East peace process.

\section{The Turbulent Middle East Region}

The Middle East remains the most turbulent of all world regions (Amirahmadi, 1993, p .3). The importance of the region to the U.S. regional strategy stems from its geopolitical location, the Israeli connection, and energy richness. The U.S influence took shape after WWII with the cold war period 1946-1958 and the Truman Doctrine of containment (1948), the Eisenhower Doctrine (1957), Kennedy's codicil flexible approach (1961), the Johnson Doctrine (1965), the Nixon Twin- Pillar Doctrine (1969), the Carter Doctrine (1980), the Regan Doctrine (1981), Clinton Doctrine (1993), and the Bush approach (2001). All published doctrines, strategies, codicils, blueprints, and foreign policy principles, such as those of Obama (2015), Trump (2019), and Biden (2021), were initiated to defend U.S. vital national interests, including key markets, energy supplies and strategic resources, against any threat, with the Middle East being the epicenter. The different U.S. administrations demonstrated remarkable consistency in terms of policy objectives to ensure the Middle East remains irrevocably part of the U.S. sphere of influence (Aruri, 1993, p. 90). They, in pursuance of national interests, have used different mechanism including military intervention, unilateral preemptive strikes, reliance on surrogates, and/or conflict resolution through negotiation and collaboration rather than confrontation and unilateralism. The main objective was to maintain the status quo in the region and safeguard the independence of allies to protect U.S. vital interests in the region. The end of the Soviet Union, however, did not end the U.S. fears of other powers meddling in the affairs of the area. The Middle East increasingly appears to be a primary ground for US-Chinese competition.

Foreign policy theorists (Rosenau, 1969, p. 45; Barber and Smith, 1974, p. 78; Frankel, 1969, pp. 185-188) argue that foreign policy-maker face a complex and fluid external environment that limits the freedom of an individual state in pursuing its national interest. Foreign policy undertakings are the output of interactions between the internal and external environments. China's efforts to establish a foothold in the Gulf area has been met with an overt or covert U.S. resentment and disapproval. The former U.S. Assistant Secretary of State for Near Eastern Affairs, David Schenker, warned regional partners against certain engagements with China that could "come at the expense of the region's prosperity, stability, fiscal viability and longstanding relationship with the United States" (Harris, 2020, June 4). China's secret works, what US intelligence believe would be a military facility at Khalifa Port 50 miles north of Abu Dhabi in the UAE, led an alarmed Biden Administration to warn the Emirati government that a Chinese military presence would not be tolerated and could threaten the strong ties between the two countries (Lubold and Strobel, 2021, Nov. 19), and contributed to halting the project (Borger, 2021, Nov. 19). The U.S., however, adopted different position on the satellite intelligence reports that Saudi Arabia is now actively manufacturing its own ballistic missiles with the help of China. Interestingly enough, Saudi Arabia's production of ballistic missiles has not received the same level of reaction despite the fact that it could complicate the Biden Administration's negotiations effort to expand the terms of the JCPOA with Iran. There are multiple reasons for this approach. On the one hand, the Biden Administration seeks to reengage Beijing on several other high-priority policy issues, including climate, trade and the pandemic (Cohen, 2021, December 23). On the other hand, it is not willing to complicate the global oil market and heighten concerns over lagging oil production by bearing down on Riyadh over these issues (Eberhart, 2021, August 14).

The Israeli variable, according to Joe Stork (1993, p. 126), represents a determining factor in the U.S. policy towards the Middle East. In part, this priority stems from the fact that a well-organized pro-Israel constituency has been developed in the U.S. whose influence is particularly great in Congress. The U.S. looks to Israel as a strategic partner constituting an integral part of its permanent interests in the Middle East ensuring its "Qualitative Military Edge" (QME) (CRS/R46580, October 26, 2020). It is perhaps for this reason that the U.S. Defense Secretary, LIoyd J. Austin III, reiterated, to the Israeli PM Naftali Bennet, in August 2021, the administration's support for replenishing Israel's Iron Dome (Taha, 2021, August 26).

The economic variable represents another element of the U.S. permanent interest shaping U.S. policy. It takes into account the extent to which the world's proven crude oil and natural gas reserves are found in the Middle East. Global crude oil reserves stood at 1,551 billion barrels at the end of 2019. Of this total, 1,227 billion barrels were held by 
OPEC Member Countries (OPEC Annual Statistical Bulletin, 2020, p. 7). At the end of 2019, proven natural gas reserves in OPEC Member Countries stood at 73.14 trillion standard cubic meters (OPEC Annual Statistical Bulletin, 2020 , p. 7). Thus, based on these current estimates, $79.4 \%$ of the world's proven oil reserves are located in OPEC Member Countries, with the bulk of OPEC oil reserves in the Middle East, amounting to $64.5 \%$ of the OPEC total (OPEC Annual Statistical Bulletin, 2020, p. 7). For natural gas, the 2019 data show that $35.4 \%$ of the world's total proven natural gas reserves are controlled by OPEC Member Countries. This increase in wealth based on energy reserves prompted an arms race in the Middle East countries, with the volume of arms imports increasing by $61 \%$ between 2010-2014 and 2015-2019 and accounting for an estimated 35\% of the total global arms imports (Stockholm International Peace Institute (SIPRI), 2020).

This regional wealth and its use to arm countries in the region has crystallized U.S. policy in the form of a de facto alliance with Israel and conservative Arab governments and impacted regional political development. The United States has continued to use its position as the world's largest arms exporter to build relationships, balance power, and thus attempt to prevent conflict (Mezran \& Varvelli, 2019, p. 23). In the period from 2000 to 2019, the U.S. supplied nearly $45 \%$ of the arms imported by the Middle Eastern countries (CRS/ R44984, November. 23, 2020, p. 2). Critics have argued that providing arms and equipment to militaries in the region has a moral cost for the U.S, as such actions defy American values and result in the death of noncombatant civilians in Yemen, Libya, Somali, and Palestine, and empower undemocratic regimes that violate human rights and contribute to political instability (CRS/R44984, November. 23, 2020, p. 9). According to Friedman, the staunch support for traditional allies encourages leaders to reach beyond their grasp, without fear of consequences. The tacit security arising from U.S, support has enabled a lot of bad behavior - boycotts, occupations, reckless adventures and brutal interventions. Biden's decision to pull back from the Middle East and the withdrawal from Afghanistan have occasioned a transition from a Middle East shaped by great powers to a Middle East shaped by its own member states. Such a transition is causing a reordering of foreign policy priorities, with a shift from resistance to resilience, encouraging allies to scramble to gain legitimacy (Friedman, 2021, October 26). The U.S. policy towards the Middle East has been shaped by multiple overlapping, conflicting, or inconsistent economic, political, and strategic interests (Amirahmadi, 1993, p. 10). By all metrics, Pax America in the Middle East has failed. The assumption that the U.S. military presence and support to the states of the region makes America and the region more secure has proved over time to be wrong. U.S. arms sales do not appear to have ameliorated the rifts within the Middle East (CRS/ R44984, November 23, 2020, p. 6). As observed by Parsi "U.S. military dominance of the area and voluminous arms sales and support for repressive regimes help drive instability and make America less safe" (Parsi, 2021, p. 5).

At the beginning of the second decade of the $21^{\text {st }}$ century, the Arab Spring came after decades of stagnant but entrenched authoritarian regimes across the Arab world. The first wave of the Arab Spring culminated in the success of the Tunisian revolution and the short-lived Egyptian revolution. Barak Obama's support to the Egyptian revolution in January 2011, though coinciding with 'American values', was perceived with suspicion by U.S. Gulf allies especially Saudi Arabia and the UAE. Obama wrote that Abu Dhabi Crown Prince Mohamed Bin Zayed (MBZ) told him that "U.S. statements on Egypt shows that the U.S. is not a partner we can rely on in the long term". Obama went on to say that "I told him I hoped to avoid having to choose between the Muslim Brotherhood and potentially violent clashes between governments and their people" (Obama, 2020, pp. 652-653). The winds of change engulfed Syria, Libya, Yemen, Bahrain and finally Sudan. Syria and Bahrain, where sectarian divisions ran high, featured privileged minorities governing large and resentful majorities. Libya ${ }^{\mathrm{vi}}$ and Yemen ${ }^{\mathrm{vii}}$ saw the worst violence. The two countries have been torn apart by civil wars and unjustified regional interventions. The Middle East has seen the largest relative regional increase of violence in the past six years. The seven civil wars in the Middle East between 2016 and 2018 marked an all-time high since 1996. In 2019, there were 10 state-based conflicts in the Middle East, two less than in 2018.

Inter-regional competition for regional hegemony intensified the involvement of all major powers in the region to "engage in funding and supporting armed non-state actors in other countries" (Parsi, 2021, p. 10). Saudi Arabia and the UAE, in their efforts to push back against political change and democratization, led a counterrevolution interventionist policy in a number of Arab countries including, Egypt, Syria, Yemen, Somalia, Bahrain, Libya and lately Tunisia. The Saudi and Emirati governments secretly supported a military coup d'etat in Egypt led by General Abdel Fatah al- Sisi to overthrow the elected president, quashing the Muslim Brotherhood movement (Riedel, 2013, July 7): It is argued that "the Gulf monarchies long believed the Muslim Brotherhood planned to come for them if it ever amassed enough power" (Hope \& Scheck, 2020, pp. 178-179). Sources claim that the UAE sees the Muslim Brotherhood as a serious threat to regime stability at home (Steinberg, 2020, July 8). UAE leaders used their joint defense pact to dispatch troops in support of the Bahraini government to defeat the opposition. President Obama explained the U.S. failure to support the Bahraini uprising by saying: "I had no elegant way to explain the inconsistency other than balancing competing interests shaped by the choices of previous administrations and the contingencies of the moment" (Obama, 2020, pp. 
652-653). He added that "We couldn't afford to risk our strategic position in the Middle East by severing relations with three Gulf countries" (Obama, 2020, p. 652).

Saudi Arabia and the UAE, encouraged by the Trump Administration, intervened, but with limited success, in Yemen and Libya. Both countries joined by Egypt and Bahrain, led an abortive and rancorous three-and-half year quadrant embargo against Qatar. They also acted as intermediaries for the Sudanese military junta to open dialogue with the U.S. and later Israel, and mediated between the putschist General Khalifa Haftar and Israel. Between 2017 and 2019, the Israeli intelligence service Mossad met with Haftar in Egypt several times. Mossad conducted training for senior Libyan

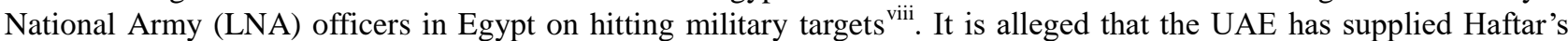
forces with an Israeli missile defense system to deter drone attacks by the Government of National Accord (GNA) ${ }^{\text {ix }}$. Abu Dhabi prefers to see a government in Libya capable of wiping out all forms of political Islam in Libya (Badi, 2020, April 21). The UAE and Egypt look at Haftar as a bulwark against Islamic militants among the internationally recognized government (El Yaakoubi, 2019, May 2). Jake Sullivan, Biden's National Security Advisor, and Daniel Benaim, a close advisor to Biden, believe that the unconditional support of the U.S. has given countries like Israel, Egypt, Saudi Arabia, and the UAE carte blanche "for destabilizing behavior" and keeping "the region on the brink of wider conflict", and they call for a demilitarized approach in the region (Parsi, 2021, p. 4).

The UAE works with many state and non-state actors throughout the Middle East and Africa to contain political Islam. The UAE has joined the coalition led by Saudi Arabia and intervened military in Yemen, initially, to deny power sharing in the post-revolution government by al-Islah Party (the Yemeni Congregation for reform), a loose coalition of tribal and religious elements with affinity to the Muslim Brotherhood. The UAE temporarily, however, shifted alliances and opened a new chapter in its relations with al-Islah, but such reproachment was short-lived. It is also alleged that the UAE vied for influence in Somalia, using al-Shabaab militia group through Somalia's illicit charcoal trade, despite the United Nations' call for a total ban in 2012, to weaken the Turkish-backed government (Worden, 2018, March 5). Ankara claims that the UAE funneled money to Turkish coup plotters in 2016 (David, 2016, July 29). The UAE air bridge in support of the Ethiopian government in its fight against insurgents from the northern Tigray region ${ }^{\mathrm{x}}$, defying Biden's strategy, also has to be viewed in the context of the fear of regional rivalries.

The U.S. post 9/11interventions in Iraq and Afghanistan claimed the lives of 801,000 people on both sides, crippled the two countries leading to sectarian civil wars and the rise of terrorist organizations like al-Qaeda and ISIS. Since late 2001, the United States has appropriated and is obligated to spend an estimated \$6.4 trillion through Fiscal Year 2020 on activities related to and caused by the global war on terror (Crawford, 2019, p. 3). At the same time, these "global war on terror" activities have become the "foremost drivers of anti-U.S. terrorism" (Parsi, 2021, p. 6). The U.S. invasion of Iraq in 2003 left a failed state. The official U.S. condemnation and isolation of the Assad regime in Syria had no real effect and allowed external and state-sponsored terrorism, leaving nearly $50 \%$ of the population displaced or living in diaspora. Barak Obama was criticized for not honoring his warning and taking more risk in 2012 and 2013 to avert the human disaster in Syria (Nye, 2020, p. 35). President Obama's decision, in 2015, not to intervene in Syria, marked a watershed towards American strategic disengagement from the Middle East (Mezran \&Varvelli, 2019, p. 19) and left Syria under greater Russian and Iranian political influence.

The failure of U.S. strategy in the Middle East and Afghanistan rendered a shift in the attitude among the American electorate. Foreign policy is not a high priority for the public, with a Charles Koch Institute poll revealing that $48 \%$ of respondents think the U.S. should be less militarily engaged in the world (Ruger, 2020, August 6). The poll also showed that three-quarters of U.S. adults support the withdraw of U.S. troops from Iraq and Afghanistan (Parsi, 2021, p. 8). Demands to end the "endless wars", inspired new approaches in the contemporary U.S. Middle East Policy. Barak Obama's policy pivot tried to rebalance foreign policy attention from the Middle East to Asia, criticizing George W. Bush's interventionist policy in Iraq and promising to withdraw troops. He pulled troops out of Iraq but was mired in the Afghanistan quagmire. Trump's Middle East policy-could be described as eclectic. He ignited the arms race and took sides in the Arab-Israeli conflict. On the other hand, he likes to be seen by the electorate as being the anti-war president, ordering the withdrawal of American forces from both Iraq and Afghanistan and leaving behind not more than 5,000 troops in both countries. For Biden, that the Middle East is not among top three priorities: "it's Asia Pacific, Europe, and the Western Hemisphere" (Bertrand \& Seligman, 2021, February 22). Biden's decision to proceed with pulling out all American troops from Afghanistan comes after a spiraling cost of the American campaign. The war since 2001 left 47,245 Afghan civilians and 69,000 troops killed with 2.7 million refugees and another 4 million displaced. Meanwhile, 2,442 U.S. troops and over 3,800 U.S. private security contractors have been killed. The conflict also killed 1,144 personnel from the 40-nation NATO coalition. It is also estimated that the U.S. spent " $\$ 2.26$ trillion on a dizzying array of expenses" (Debre, 2021, April 30).

The Arab-Israeli conflict has been and remains a primary source of instability in the region. The U.S. has to reconcile competing national interests in the Middle East. Richard Cottam has argued that the U.S. policy towards the Arab-Israeli 
conflict is paradoxical in nature (1993, p. 57). Joe Stork argues that:

'The U.S. interests in the Middle East are determined on the basis of strategic considerations and access to resources and market. On these grounds, the strategic location of the Arab world, the concentration of the world's most accessible crude oil reserves, and the extensive market for the American goods and services - Israel appears to be a relatively insignificant and one would expect a policy more solicitous of Arab, and Palestinians, interest'(1993, 126).

While Joe Biden vowed to bring home all combat troops from the Middle East, his administration is the first American administration to say that the Palestinians and Israelis deserve equal rights. He spoke of a Two-State solution and a restoration of diplomatic relations with the Palestinian Authority. However, the durability of the U.S. commitment to fulfilling such a pledge remains to be seen. The U.S. commitment to the status quo in the region has been so resolute that American efforts towards the Arab-Israeli conflict have always tilted to support Israel. Biden's pledge to work for a Two-State solution is not likely to have a significant impact on the Middle East peace process because of other factors determining U.S. policy towards the region. Instead, he will probably pursue a more conventional U.S. approach towards the conflict, reversing his predecessor's policy and adopting Henry Kissinger's incremental step-by-step approach (Cottam, 1993, p. 56). Biden's policies since the inauguration of his Presidency signal a return to a more traditional evenhanded policy to the conflict (Crowley, 2021, January 26).

\section{U.S. Peace Diplomacy in the Middle East Region}

U.S. relations with Israel go back to Harry Truman who stood up to the Secretary of State George Marshall who opposed the creation of the state of Israel (Nye, 2020, p. 82) and to his Secretary of Defense, James Forrestal who was a vigorous opponent of U.S. support for the Zionist project (Stork, 1993, p. 127). The Truman administration pushed for the 1947 partition of Palestine resolution supporting the birth of the state of Israel. The relationship between the U.S. and Israel has now progressed to the point of becoming a strategic partnership. "Support for Israel is considered a bipartisan priority and for decades has been perceived as the most stable item on U.S. foreign policy agenda" (Baroud, 2020, December 28). The only time the U.S. stood against Israeli in any regional conflict was during the Suez Crisis in October 1956. Dwight Eisenhower cautioned Khrushchev to refrain from direct intervention in the conflict, and issued a stern warning to the British, French, and Israelis to withdraw from Egyptian soil (Editors/ History, 2021, April 27). The U.S. took the side of Israel in the Six Days War of 1967 and the Yom Kippur War of 1973 pledging to directly intervene to support Israel if the balance of power was seen to be tipping in favor of the Arabs (AlAlkim, 2011, pp. 176-183). It is argued by Richard Cottam that, following the cease fire to the 1973 war and Israel reluctance to withdraw its forces encircling the Egyptian army, the Soviets, on October $24^{\text {th }}$, suggested to the U.S. government either a joint intervention to enforce the cease fire, or a unilateral Soviet move to do so. "The American response was to place its forces on nuclear alert" (1993, p. 53). Moreover, between 1972 and 2018, the U.S. vetoed 44 resolutions at the U.N Security Council to block critical resolutions against Israel (Jewish virtual library, 2018, June 1). The U.S. foreign assistance to Israel, since World War II, is estimated at $\$ 146$ billion (CRS, R44984, 2020, November 16). U.S. military aid for Israel is designed to ensure Israel's "Qualitative Military Edge" (QME) in the region. The Israeli Defense Forces (IDF) became the first foreign operator to acquire 50 of the F-35 Joint Strike Fighter, funded with U.S assistance. The Obama Administration increased funding to Israel by a significant margin, to counter the efforts of the Republicans to align the party more closely with Israel. Benjamin Netanyahu's philosophy of strength "aligned him with the most hawkish member of AIPAC, and American right wingers" (Obama, 2020, p. 630). Obama was the first U.S. President to have imposed no limits on Israeli settlement expansion. He vetoed a Security Council resolution, on February $18^{\text {th }}, 2011$, calling for ending settlement expansion (Chomsky, 2016, pp. 137-139). However, Obama before ending his term, changed position and decided to abstain on Security Council Resolution 2334 condemning Israeli settlements (Bard, 2021). During the period of Donald Trump, 2016-2020, the U.S.-Israeli alliance was further consolidated, through several political initiatives and projects.

Trump entered the White House speaking of his desire to achieve the "Ultimate Deal" or the "Deal of the Century". Trump's policy represented a fundamental shift from previous successive U.S. administrations. He changed positions from being critical of Netanyahu (Woodward, 2020, p. 66) to accepting the Israeli right-wing interpretation of the conflict. It is alleged that Netanyahu managed to change Trump's perception of the conflict, during the latter's visit to Israel in May 2017, using a faked video that sounded like Abbas was ordering the murder of children. Alex Tillerson, then Secretary of State, tried in vain to convince Trump that the whole thing was fabricated. According to Bob Woodward, Trump during his meeting with Abbas in Bethlehem on May $23^{\text {rd }}, 2017$, accused the Palestinian leader of "being a murderer and a liar" (Woodward, 2020, pp. 65-66).

Trump's Administration adopted a series of controversial policies including recognition of Jerusalem as the eternal undivided capital of Israel and moved the U.S. Embassy there (Alghafli, 2019, p. 102). Trump also recognized Israeli 
sovereignty over the Golan Heights and the Jordan Valley, occupied in the 1967 war. The Palestinians rejected the U.S. unilateral steps and in December 2017, the Palestinians boycotted Kushner's peace plan and froze contacts with Trump's Administration. In a further pro-Israeli move, Trump, in September 2018, ordered the closure of the Palestinian Authority office in Washington, canceled U.S. aid to the West Bank and Gaza, and froze the \$360 million in annual aid to the UN Relief and Work Agency (UNRWA). In November 2019, U.S. Secretary of State, Mike Pompeo, said that the U.S. had abandoned its four-decade-old stance, on Jewish settlements. On January $20^{\text {th }}$ 2021, Donald Trump granted full pardon to Israeli spy Aviem Jonathan Pollard, a former Navy intelligence analyst accused of selling secrets to Israel while working at the Pentagon in the 1980s, after thirty-five years of imprisonment and house arrest (Rubin, 2020, December 30), a move other U.S. Presidents refused to take despite the Zionist lobby pressure.

Trump's Administration brokered normalization of relations with a number of Arab states (see below). He did not hesitate to bully the Arab states to conclude peace agreements with Israel. The Pentagon announced on January $15^{\text {th }}$, 2020, that it was transferring Israel from U.S. European Command (EUCOM) to U.S. Central Command (CENTCOM). The significance of this move is in the change of long-standing intelligence-sharing practices between Western and Arab allies. Israel's integration into the Central Command will strengthen intelligence-sharing on operations in the Middle East, that include Arab countries like Saudi Arabia, with whom it has no formal relations yet (Intelligence Online, 2021, January 27).

In an attempt to reverse this dramatic shift in American policy, Biden called for a return to a Two-State solution initiative and for the Palestinians to enjoy equal rights. Biden's call to Benjamin Netanyahu on February $17^{\text {th }}, 2020$, came one month after inauguration, reaffirmed U.S. commitment to Israel security, and support for the Israeli normalization agreement with Arab countries (Sink, 2021, February 17). Interestingly, it has been argued that mother nature could help Joe Biden to employ ecosystem diplomacy to reengage in the Middle East peace process. For example, Jordan has vast desert areas suitable to produce large amounts of cheap solar electricity to meet its own needs and to sell to the Israeli and Palestinian grids to "generate the electricity for desalination plants that could provide all three parties abundant fresh water. Israel on October $12^{\text {th }}, 2021$ signed an agreement to double the freshwater to 105 million cubic meters it provides annually to Jordan ${ }^{\mathrm{xi}}$, in line with the "Green Blue Deal ${ }^{\mathrm{xi} i}$ ", (Friedman, 2021, October 26). In a further development Israel and Jordan signed a water for energy pact funded by the UAE and backed by the U.S. (Avis, 2021, November 17).

\section{Peace Agreements between Israel and Arab Countries}

The U.S. strategy in the Middle East has revolved around the necessity to achieve peace and integrate Israel in the wider Middle Eastern regional security system (AlAlkim, 2011, p. 207). The U.S. efforts to normalize relations between Israel and Arab countries started with Henry Kissinger's 'dubious shuttle diplomacy'xiii, during the Richard Nixon Administration. In the aftermath of the October 1973 war, Kissinger managed to broker a few agreements between Israel and Egypt, Syria and Jordan, but the Watergate Scandal prevented President Nixon from playing any major role in guiding U.S. foreign policy (Yacub, 2008, April 22). Kissinger's engineering a cease fire between Israel and Egypt and Syria in the October 1973 war has kept the Golan Heights under Israeli occupation until today. He orchestrated a step-by-step process for managing the crisis but not ending it (Cottam, 1993, p. 53). Kissinger's complexity illustrates the role of political Zionism and pro-Israel Zionist government advisors in the U.S. political establishment. Kissinger candidly revealed, to private American Jewish leaders in June 1975, his post 1973 goals as to break up the Arab united front, ensure the Europeans and the Japanese did not get involved, keep the Soviets out of the diplomatic arena, create a situation that would enable Israel to deal separately with each of its neighbors, and leave the Palestinians alone, hoping eventually to isolate them (Stork, 1993, p. 135).

The U.S. role in brokering peace agreements between Israel and the Arab states never stopped, but efforts fell short of achieving a permanent and lasting peace. The first peace agreement was the Camp David Accords signed on September $17^{\text {th }}, 1978$ between Israel and Egypt followed by the Oslo Accord on September $13^{\text {th }}, 1993$ with the Palestinians Authority, Wadi 'Araba with Jordan on October $26^{\text {th }}$, 1994, the Oslo Two Accord, the Interim Agreement on the West Bank and the Gaza Strip, signed on September 28, 1995, and ended with the short-lived agreement with Mauritania on October $28^{\text {th }}, 1999$. However, the U.S.-backed peace talks broke down in 2014 because of what became to be known the 50-Days War. The IDF, on July $8^{\text {th }}$, launched the 'Operation Protective Edge' against Gaza that left behind more than 2200 Palestinians and 71 Israeli dead (Dearden, 2014, August 27).

The Trump Administration aligned itself with the conservative Arab regimes, supporting Israel, alienating Iran, and campaigning for the Deal of the Century. Trump's Administration, through its stick and carrot policy, managed to broker peace agreements between Israel and four Arab countries: Bahrain, Morocco, Sudan and the UAE, each for its own reasons, with the pretext of fighting Islamic political insurgency being the common dominator. Islamist parties have managed to score points with the public against traditional Arab leaders by showing their failure to help the Palestinians 
struggle (Slackman, 2009, January 11).

The new thinking in the UAE foreign policy, represents a shift from an Arab consensus adopted during the 2002 Arab Summit in Beirut which calls for the independent Palestinian state based on the UN Resolutions 242 and 338 (AlAlkim, 2011, pp. 202-231) to a narrowly defined national interest approach. This shift has inspired the UAE unilateral foreign policy initiative towards the Arab-Israeli conflict. The U.S. sponsored peace agreements between Israel and both Bahrain and the UAE were signed on September 15, 2020. The UAE Ambassador to Washington, Yousef al-Otaiba, justified, on February $1^{\text {st }}, 2021$, the move, in terms of "preventing annexation" of large parts of West Bank and saving the Two-State solution initiative (Magid, 2021, February 2). Mohamed Bin Zayed, in an interview with Robert Satloff from the Washington Institute for Near East Policy, on November 19, 2021, justified the UAE step by saying:

"For us, this is an important decision for many reasons. First, for the Palestinians themselves. Second, to send a clear message to the world and the region that we are striving for peace. Third, it is a mission that we have inherited from our founder, the late Sheikh Zayed, God rest his soul. He was a man of peace and compassion, since the days of the UAE's inception. That is his vision, and we are committed to this path" (Satloff, 2021, November19)

The pretext used to justify the move, however, did not prove to be realistic. The Naftali Bennet government announced on October 27. 2021, its plan to construct more than 3000 new settlement units in the occupied West Bank (Kingsley, 2021, November 4) and on December 26, 2021 announced to double settlement in Golan Heights.

The UAE and Israel have a geopolitical interest in cooperating to contain Iran and its proxies in Lebanon, Syria, Iraq and Yemen, and in curbing Sunni Islamic radicalism. The UAE unilateral move is best understood as an arm deal and implicit defense pact. Abu Dhabi aims to have an Israeli defense umbrella against any potential Iranian threat, and contain Sunni Islamic resurgence. The UAE was also hoping to strengthen its air force with the F-35 fighters that Trump has promised in return for signing the Abraham Accord. The peace accord opened the way for the UAE to request the U.S.'s most advanced fighter jet, the F-35, the support of the Zionist Jewish lobby in Washington, and security cooperation with Israel. As a result, the U.S. has called Bahrain and the UAE "major security partners" (Gambrell, 2021, January16). Trump's White House approved the sale of 50 F-35s to the UAE in late 2020 (CRS, R44984, November 23, 2020, p. 8). It is also alleged that the peace agreement comes as a natural result to the UAE- Israel de facto long existed relations. Reports claims that Israel has established, since early 2019, a secret military base in the UAE 330 meters underground that can withstand any missile attack (Swan, 2021, September 23).

UAE-Israeli relations are steadily growing, more so than any other Arab-Israeli relations. Cooperation includes political, military, economic and scientific fields. The UAE and Israel exchanged diplomatic missions. Mohammed Mahmoud AlKhajah, became, on Feb. 15, 2021, the first UAE Ambassador to Israel. On July $26^{\text {th }}$, 2021, Israel reciprocated by appointing its first Ambassador, Amir Haik, to Abu Dhabi. Abu Dhabi Crown Prince, Mohamed bin Zayed extended an official invitation to the Israeli Prime Minister, Naftali Bennet, to visit Abu Dhabi (Berman, 2021, October 19). The UAE Air Force Commander, Ibrahim al-Alawi, visited Israel to take part in a conference for countries flying the F-35 during the large-scale international Blue Flag aerial exercise (Ahronhem, 2021, October 25). Earlier in 2021, Israeli and Emirate pilots jointly participated in the U.S.-led air force drill hosted by Greece (Gross, 2021, October 25). Moreover, sources believe that the Israeli government has supplied the UAE with some advance defense equipment (CRS/R46580, 2020, October 26, p. 6). The two countries also reap economic benefit from the formalization of a relationship. Data show that trading volumes between the UAE and Israel jumped from \$51 million in the first seven months of 2020 to $\$ 614$ million over the same period in 2021 (see table below). The tourist exchanges between the two countries witness significant momentum with around 250,000 Israeli tourists visiting the UAE since the establishment of relations until October 2021. In a private venture, touted as one of the most immediately lucrative products of the Abraham Accords, the two countries signed on October 19, 2020 a fuel shipping agreement to transport oil from the UAE to Europe via a pipeline that connects the Red Sea city of Eilat and the Mediterranean port of Ashkelon originally built in 1968 to transfer Iranian oil (Rabinovitch and Cohen, 2020, October 20). The UAE and Israel have signed a number of agreements to promote educational and scientific collaboration that could see the two nations' flags jointly planted on the moon by 2024 (Ben-David, 2021, October 2). In addition, A UAE educational delegation, led by the UAE Minister of Education Hussein Al Hammadi, visited Tel Aviv early November 2021 and concluded cooperative agreements, and Zayed University has executed an agreement with Haifa University as well. In a sign of deepening ties, Naftali Bennett became the first Israeli Prime Minister to pay 2-days official visit to the UAE, on December 12, 2021, and met with Abu Dhabi Crown Prince Mohamed bin Zayed to discuss future economic and military cooperation.

The UAE has played the godfather role in assisting the Trump Administration with normalizing the relations of other Arab countries with Israel. In Sudan, the UAE's role extended to facilitating Sudan's recognition of Israel. The UAE, in February 2020, arranged for a secret meeting in Uganda between General al-Burhan and the then Israeli Prime Minister 
Benjamin Netanyahu, without the involvement of the Sudanese Prime Minister Abdulla Hamdok (Dorsey, 2021, November 2), in return for a Saudi-Emirati pledge of $\$ 3$ billion in aid. Sudan, hoping to end U.S. embargo, saw the peace deal with Israel as a window of opportunity for global outreach. To salvage the Israel-Sudan deal, the U.S. offered to pay $\$ 700$ million of U.S. funds to 9/11 victims, on behalf of Sudan, although Sudan was not found to have a role in the attack (Finnegan, 2020, December 12). Consequently, Sudan was removed from the U.S. State Sponsor of Terror list (Bearak \& Mohieddin, 2020, December 4). Trump also, in his last days in office, with the help of Abu Dhabi, brokered another peace deal between Israel and Morocco in return for U.S. recognition of Morocco's control of the disputed Western Sahara territory (Jakes et al, 2020, Dec. 10). The scope of trade between Israel and the Arab Countries, as a result of the peace agreements, grew significantly by 234 per cent in the first seven months of 2021 to $\$ 981.6$ million compared to the same period in 2020 (Gonen, 2021, September 3) with the UAE taking the lead.

Israel's Foreign Trade (M./U.S. D)

\begin{tabular}{|l|l|l|}
\hline Country & Jan.- Jul 2020 & Jan.- Jul. 2021 \\
\hline UAE & 50.8 & 613.9 \\
\hline Jordan & 136.2 & 224.2 \\
\hline Egypt & 92 & 122.4 \\
\hline Morocco & 14.9 & 20.8 \\
\hline Bahrain & 0 & .3 \\
\hline Total & 293.9 & 981.6 \\
\hline
\end{tabular}

Source: Israel Central Bureau of Statistics

Arab-Israeli relations are not limited to those with whom Israel established diplomatic relations since Tel Aviv enjoys de facto relations with many other Arab countries such as Oman, Qatar, and Mauritania. Benjamin Netanyahu paid a state visit to Oman and was received by the late Sultan Qaboos on October 26, 2018. The visit, however, was not the first by an Israeli Prime Minister to Oman. Yitzhak Rabin secretly paid the first visit to Muscat on December $27^{\text {th }}$, 1994 followed by Shimon Perez's visits to Oman and Qatar on April $1^{\text {st }}, 1996$. He was received by Sultan Qaboos and the then Emir of Qatar sheikh Hamad Bin Khalifa al-Thani and opened trade representative offices in both countries. Mauritania's diplomatic relations with Israel was brokered by the U.S. in 1999 but were eventually frozen and finally suspended in 2010 after Israeli aggression against Gaza during 'Operation Cast Lead' 2008-2009 (Cafiero, 2020, September 25). However, many of the commercial and industrial ties to Israeli corporations still persist if nothing more than for the reason that Israeli penetration of Mauritanian markets was significant (al-Kurwy and Abbas, 2011, pp. 30-50). Qatar and several other Arab states ended an economic ban on Israel after it signed interim peace accords with the Palestinians in 1993, but relations worsened after a Palestinian uprising broke out in 2000 (Rihawi, 1996, April 2)

Trump's Administration represented by Kushner started pushing the Saudis for a rapprochement with Israel. Kushner proposed in a meeting with a Saudi delegation at Trump Tower, in 2016, that the Saudis make progress towards normalization with Israel. Mohamed Bin Salman, in an interview with Jeffrey Goldberg, that appeared in The Atlantic magazine, during his visit to the U.S. in March 2020, asserted Israel's right to exist (Hope \& Scheck, 2020, p. 285). Mohamed bin Salman, in a conciliatory gesture, permitted Trump's plane to use Saudi air-space, for the first time, to fly direct from Riyadh to Tel Aviv. He also opened Saudi air-space for Israeli El Al commercial flights to the UAE and Bahrain. Bahrain itself would not have agreed to establish diplomatic relations with Israel without Saudi consent. The development of the de facto relations was culminated in the secret meeting held at the Red Sea city of NEOM between Mohamed bin Salman and the Israeli Prime Minister, Netanyahu, who paid for the first time an unannounced visit to Saudi Arabia on Sunday November 22, 2020. (Holmes, 2020, November 23). Saudi Arabia, for the first time, decided to open up for Israeli tourists. Other conciliatory moves by Crown Prince Mohammed bin Salman include his stewardship in modernizing the kingdom's religious education system and encouraging the religious establishment to replace "extremist narratives" against the Jews in school textbooks with "a moderate interpretation" of Islam. Such moves were intended to prepare Saudi public opinion for eventual recognition of Israel.

The new thinking in the Saudi establishment, according to Zvi Bar'el, is causing a rift in the House of Saud. Prince Turki al Faisal, at a virtual security conference held in Bahrain on December 6, 2020, blasted Israel, accusing her of bullying, stealing land, and putting the Palestinians in concentration camps (Nereim, 2020, December 6). The position of the Islamic reformist leadership ${ }^{\text {xiv }}$ towards Hamas puts pressure on the Monarchy not to be less Islamic than Hamas in serving the Palestinian cause. Otherwise, the Monarchy's Islamic legitimacy would be threatened (al-Shamsi, 2011, p. 184). In a move inconsistent with preparations for recognizing Israel, Saudi Arabia unilaterally amended its rules on imports from other GCC countries to exclude goods using Israeli components, made or produced in Israel, or manufactured by companies owned fully or partially by Israeli investors or by companies listed in the Arab boycott 
agreement from preferential tariff concessions (el- Yaakoubi et. el, 2021, July 5). The rationale behind this policy is debatable, and possible explanations include the cooling of Saudi-UAE relations ${ }^{\mathrm{xv}}$, the internal Saudi father-son differences on the Palestinian question, Islamic leadership pressure, or purely economic considerations to promote domestic products or increase the Saudi custom tariff income.

The limited success of the U.S. in engineering these agreements with Israel can be understood in terms of the Arab governments, understanding of their inherited weaknesses and loss of legitimacy and their looking to Israel as a security guarantor and a gateway to the U.S. On the other hand, Israel realizes that the Arabs states will continue to represent a threat to its security and stability unless they are accommodated. Simultaneously, both parties share similar existential threats, with varying degrees, including Iran and most importantly the Sunni Islamic revivalism. Interestingly enough, the Arab states have always found themselves in the same camp with Israel when their security is at stake. They and Israel are part of the U.S. regional security strategy and their role is to enhance "mutual security" which is existential, and outweighs their differences (AlAlkim, 1994, p. 131).

The Israeli role in regional stability, however, is viewed with suspicion. It is possible that an agreement with Israel will exacerbate regional instability because of local political, social and cultural resentment and regional tension. Such agreements may prolong tension in the region and instability in Syria, Libya and Yemen (Pack, 2020, August 21). The Palestinian cause has always been an explosive, emotional and destabilizing factor for Arab states (Slackman, 2009, January 11). The UAE recognition of Israel caused covert social resentment and division and potentially undermines the religious soft power of the Emirates. James Dorsey argues that the UAE has destroyed its long-standing efforts to project itself as a model of Islamic moderation and tolerance and a force for peace. The UAE move has sparked splits within the Sufi new traditionalism movement led by Abdulla bin Bayyah, created and nurtured by Abu Dhabi, and thus damaged the country's efforts to project an image of a moderate religious power (Dorsey, 2020, September 10). The Palestinian Authority condemned the move and called the Abraham Accord a "stab in the back" and temporarily recalled its ambassador from Abu Dhabi. This uncertainty with regard to the future of greater collaboration between Arab states and Israel underscores the difficulty faced by the Biden Administration in trying to incorporate such bilateral agreements into a comprehensive strategy for the Middle East region.

\section{Challenges to Resurrecting the Two-State Solution}

Factors shaping foreign policy are usually colored by the incumbent president's perception or interpretation of the implication of a given foreign issue vis-à-vis its relation to the pursuance of the national interest. The willingness to pursue a specific initiative will depend on its potential impact on the national interest and the degree to which that impact is clear. Joe Biden, with 35 years' experience in Washington, appreciating the strength of the Israeli lobby and its influence on successive administrations, understands that Israel security is a primary permanent interest (Mearsheimer and Walt, 2008, pp. 204-229). He will not risk deviating from the long-standing support for Israel but also will not continue to pursue Trump's policy towards the Middle East conflict. Biden, in his campaign, rejected the idea to withdraw military aid, as others have suggested, from Israel and called it 'bizarre' (Arria, 2019, December 9). On the other hand, he campaigned on a long history of criticizing the construction of Jewish settlements in the 1967 Palestinians occupied territories. Rather than falling into the ostensible honey-trap that allured his predecessor, the new U.S. President calls for a roll-back strategy consistent with the previous U.S administrations" (Magid, 2021, January 29). Although Biden's Administration supports the peace agreements concluded, he is a firm believer that a Two-State solution is the only option for resolving the Palestinian issue (Slackman, 2021, June 11). However, Biden was criticized when he spoke at the UN General Assembly in September 2021, of a "Jewish state" appearing to acknowledge the existence of an apartheid state ignoring the rights of the 20\% of its residents who are Palestinian Arabs living in the pre-1967 territories. On the other hand, Biden did revoke many of Trump's executive orders resulting in the release of U.S. financial assistance to the Palestinians, the reopening of the U.S. Consulate in East Jerusalem, despite Israel's rejection of the move (Harkov, 2021, October 21), and the release of U.S. financial support to the UNRWA. Biden's Administration considers the settlements provocative and a major impediment to efforts to achieve the Two-State solution. The Israeli plan to construct new settlement units in the occupied West Bank received the sharpest rebuke yet (Lewis \& Parmuk, 2021, October 27).

The Biden Administration came to office hoping to deprioritize the Israeli-Palestinian conflict. Members of the administration saw Washington-led negotiations as a trap that had ensnared previous U.S. administrations (Goldenberg, 2021, Jun. 21). Therefore, they prefer pushing incremental steps that can be taken by the parties to the conflict while discouraging unilateral moves that would erode whatever confidence still remains between the sides (Magid, 2021, January 29). However, the eleven-day war that erupted in Gaza in May 2021 presented a major foreign policy challenge for Joe Biden and forced the administration to reorder its priorities (Zengerle et. al., 2021, May 22).

The Gaza crisis was caused by the raid on Al Aqsa Mosque compound on May $10^{\text {th. }} 2021$ by militant Jewish settlers and police that left hundreds of Palestinians injured. President Biden held six phone calls with Netanyahu to push for a 
ceasefire (Ravid, 2021, May 22). The Biden Administration had three immediate demands of Israel: stop evictions in Sheikh Jarrah, lower tensions on Temple Mount, and cancel the annual Jerusalem flag day parade. Joe Biden pursued a dual strategy: backing Israel in public while urging Netanyahu in private to immediately end the operation and minimize civilian casualties. Biden was adamant not to call for a ceasefire in public or engage with the issue at the United Nations Security Council. The escalation of the confrontation led the U.S. to deal with the Egyptian government and speak to Abdel Fattah al-Sisi, for the first time since Biden took office in January 2020 (Hendawi, 2021, May 21). The administration sought to engage Egypt to mediate with Hamas, and, only after eight days, started calling, in public, for a ceasefire. Biden warned Netanyahu that continued fighting would spiral out of control and informed him that he expected a "significant de-escalation today" with a path laid towards a ceasefire in Gaza (Shesgreen, 2021, May 19). However, Biden was criticized for not applying greater pressure to immediately end the conflict and prevent the killing of 248 Palestinians and the displacing of thousands of others.

\section{Iran and the Middle East Peace Process}

The other variable that could impact Biden's peace diplomacy is the Iranian factor. The Biden Administration's efforts to bring Iran back to the Joint Comprehensive Plan of Action (JCPOA) are expected to mollify Tehran somewhat. The overture may lead the Iranian leadership to refrain from criticizing the Israeli peace agreements with Arab neighbors and pave the way for a new regional détente that could ultimately lead to a long-lasting peace in the Middle East (AlAlkim, 2021, p. 390). The linkage between bringing Iran back to the JCPOA and regional stability is very strong. This is clearly manifested in the Iranian Foreign Minister Amir-Abdollahian's announcement, on January $6^{\text {th }}$, 2022, of the positive progress in the Vienna negotiations to revive the 2015 Iran nuclear deal and the progress in the diplomatic dialogue with Saudi Arabia.

Biden's Administration perceives Iran as the epicenter of regional conflicts and insecurity. Therefore, accommodating Iran, through the return to the JCPOA, would help manage regional conflicts including the protracted Middle East conflict. The U.S. considers Iran as a threat to Israeli security from two perspectives: 1) Iran's maximalist and militant approach towards the Arab-Israeli conflict and the support it overtly extends to to Hamas and Hezbollah, on the one hand, and its alliance with the Syrian regime on the other; 2) the Iranian nuclear program and its impact on regional balance of power, particularly Israeli security. The Iranian military assistance and know-how enabled Hamas to make its own missiles and create a semi-deterrence with Israel. Consequently, Iran and Israel have been caught up in a cold war exchanging hostile messages and engaging in proxy wars, assassinations, malicious cyber activities, and tanker skirmishes. The prevailing regional animosity has exacerbated the proliferation of weapons of mass destruction (WMD), and has intensified the arms race. Since the U.S. unilateral withdrawal from JCPOA, Iran's nuclear capabilities have increased greatly to exceed their status in July 2015 when the deal was concluded. It is argued that Iran needs only a few months to produce enough weapons-grade uranium for a single bomb. (Dorsey, 2021, October 4).

With its multiple violations of the JCPOA, Iran has reached uncharted territory, accumulating important knowledge, experience, and practice. Another possibly irreversible set of actions concerns Iran's illicit procurements for its nuclear programs, some of which appear to have violated the JCPOA's procurement channel provisions. Iran is well known to have procured illicitly for its nuclear program perishable items for its gas centrifuge programs (Albright, 2021, September 22). The report on Iran's achievements has sparked public debate in Israel, being the only regional state with an advanced nuclear arsenal and not a member of the Treaty on the Non-Proliferation of nuclear weapons (NPT) (Chomsky, 2016, p. 141). The debate concerns whether Israel should finally confirm its nuclear capabilities, and, in so doing, lay down a marker for Iran. It is alleged that the Israeli nuclear capability acted as a deterrent ${ }^{x v i}$ in the October 1973 war (Sagir, 2021, Sept. 30). The Enhancement Integrated Framework (EIF) formula for the Middle East zone treaty will depend on how Israel is included in the arrangement. The formula would require a shift in the Israeli policy to acknowledge its nuclear capabilities. A treaty of this nature is part of a larger regional process of substantially reducing tensions, curtailing the arms race, and mitigating risks. However, Israel will likely require assurances that the zone arrangements are effective before it would irrevocably commit to the zone. Acknowledgement of its nuclear arsenal would potentially force Israel to join other key Middle Eastern countries, including Iran, as a signatory to the NPT (Carlson, 2021, pp. 41-44). The U.S. and Israel demand a regional security arrangement to ensure Israel's security as a prerequisite to eliminating weapons of mass destruction (Chomsky, 2016, p. 141). This would create an opportunity for Joe Biden's Administration to rejigger the United States' commitment to the region's security and its management of regional conflicts.

\section{Findings}

The findings of the current study can be summarized in the following points:

1. The U.S. will remain a leading actor and important military power in the region for decades to come. The Biden's national interest approach towards the Middle East is a tweaked version of the Obama-Biden foreign policy with an incremental 'step-by-step approach' towards the peace process despite his emphasis on a Two-State solution to end the 
conflict. The Biden's doctrine of de-emphasizing military engagement creates uncertainty about the U.S. commitment to the Middle East security. The study reveals that the Biden's Administration is less inclined to play a unilateral role and prefers to pursue what Morgenthau describes as a 'community of interests' approach (Robinson, 1969, p. 187)) with more international involvement, designed to lay the foundation to encourage the Middle East countries to engage in substantive dialogue. The assumption is that, with the international powers' encouragement, constructive engagement could lead to de-escalation of the conflict, promote confidence building measures, and initiate talks between the regional actors to reach a peaceful settlement based on a Two-State solution and the establishment of a regional security forum.

2. The U.S. domestic environment, especially the pressure groups, plays a significant role in shaping the U.S. foreign policy (Millar, 1969, p.62) towards the Middle East. The Israeli lobby, especially the American Israel Public Affairs Committee (AIPAC), plays an influential role in the U.S. real politic (Lilienthal, 1978; O'Brien, 1986; Mearsheimer and Walt, 2008; Felton, 2018) that impacts U.S. foreign policy towards the Middle East (AlAlkim, 1988, pp. 212- 226). The Zionist Jewish influence is clearly manifested in the political and financial support the American Zionist Jewish community provides to the Democratic Party. Members of the Jewish community not only finance the electoral campaign of the Democrats but make an influential voting bloc in key states like New York and California. This becomes more important with the Democrats' desire to maintain their loose grip on the Congress and the remote possibility of gaining control in the mid-term election in 2022, on the one hand, and the possibility of Joe Biden running for a second term in 2024, on the other hand. Neither can be realized without securing the Zionist Jewish vote, in general, and the Jewish lobby's financial support, in particular. These considerations help convince the American political elite to support Israel (Stork, 1993, pp. 129-130).

The increasing influence exercised by the Christian white evangelicals in contemporary U.S. political life, that increased from 25\% of the U.S. population in 2016 to 29\% in 2020 (Smith, 2021, September 15), and the checks and balances they play in power sharing with the Democrats force Joe Biden's Administration to pursue a conciliatory approach and call for collective bipartisan foreign policy based on a macro-level assessment of U.S. national interests represents. Hence, compromising values to pursue national interests will continue to persist in U.S. policy towards the region. This is reflected in the U.S.'s unconditional support for Israel's QME despite Israel's indifference to the United Nations resolutions, especially 194, 242, and 338, its failure to heed the international community 's call to end settlements in the Palestinian territories and to stop evictions of Palestinians from their homes, and Israel's violation of Palestinian human rights in denying them the right to self-determination. U.S. administrations have made no serious efforts to secure Israel's compliance with international resolutions regarding the conflict nor is such pressure expected of the current Administration.

3. Joe Biden's push for Iran's reengagement in the JCPOA could ultimately intersect to influence the Arab-Israeli conflict. A shift in Iran's position in the conflict from resistance to resilience would contribute positively to the Middle East peace process and could encourage constructive regional engagement that would eventually help the U.S. broker a regional long-lasting peace. The Two-State solution would bring some relief for the Palestinian living in diaspora. However, this will depend on the extent of U.S. willingness to undertake far-reaching engagement in the conflict.

\section{Conclusion}

The above analysis of the Biden Administration's foreign policy towards the Middle East has supported the hypothesis that, despite the de prioritization of the Middle East, the U.S. is only pulling back not pulling out entirely. The current analysis has also shown that U.S. foreign policy is best understood through the lens of an interest- driven foreign policy model. This conclusion is substantiated by the argument that, regardless of whoever is in the White House, the U.S. will continue to pursue its national interests at all costs. The permanent interest approach supports the assumption that the U.S. will continue to playing a leading global role for the foreseeable future. Securing U.S. permanent interests in the region and maintaining the status quo are intertwined. The U.S. will still be needed to deter Iran, should it develop a nuclear capability and to defuse other conflicts (Friedman, 2021, October 26). The U.S. Defense Secretary Lloyd Justin III, traveled to Bahrain on November 20 ${ }^{\text {th }}$, 2021, in an effort to convince Arab States that the U.S. would remain engaged in the Middle East (Cooper, 2021, November 20). Biden's call for a Two- State solution and his declaration that the Palestinians deserve equal rights represents a significant shift from his predecessor, and an important signal of the Democratic administrations' perceptions of the conflict. However, the Biden Administration's role in the Middle East peace process will be limited to managing the crisis rather than ending it. The political context in the U.S. has forced him to adopt a pragmatic approach intended to satisfy the progressives within the Democratic party and the pro-Israeli lobby in Congress. Biden, in his first year, was unable to deliver his campaign promises towards the settlement of the Arab-Israeli conflict and is unlikely to be able to do so in the future. He has limited his role to only criticizing Israel's unilateral steps of further annexation of pre-1967 Palestinian land, but no concrete action has been taken to stop the building of new settlements. 
The new Israeli Prime Minister, Natali Bennet, has put to bed_hope for progress (Lis, 2021, September 1). He has unequivocally rejected the notion of an independent Palestinian state alongside Israel, approved more settlements, refused to negotiate peace with the Palestinians during his term, suggesting that the improvement of social and economic conditions would satisfy Palestinian's aspirations. Some 600,000 Israelis who populate settlements built on the West Bank, Golan Heights, and in East Jerusalem make Two-State solutions de facto impossible. That would leave a secular democratic one-state as the only solution. However, either a one-state or a two-state "solution" that ignores the fundamental rights of Palestinians confers legitimacy on an apartheid religious state. The current U.S. position on the conflict is likely to last until there is either a fundamental shift in Americans public opinion due to demographic change or a new wave of Arab uprisings challenging U.S. national interest in the region erupts.

Regional instability is further exacerbated as a result of the alienation existing between Arab governments and their people. Therefore, Arab states' relations with Israel risk being built on a weak and fragile foundation. Criticism echoing in various Gulf states suggests that Palestine remains an emotive public issue and a major public foreign policy concern. Political groups, civil society organizations, trade unions, and professional associations in the Arab countries are supportive of the anti-Israel boycott. More than half the members of Kuwait's Parliament insisted that there could be no normalization without a resolution of the Palestinian question. Oman's grand mufti, Ahmed bin Hamad al-Khalili, sought to pre-empt potential Omani aspirations of following in Bahrain's and the UAE's footsteps by declaring the liberation of the occupied land "a sacred duty"xvii. Polling by James Zogby, a Washington-based pollster, showed Palestine ranking in 2018 as the foremost foreign policy issue in Emirati and Saudi public opinion. In the same year, Arab Opinion Index suggested that $80 \%$ of Saudis see Palestine as an Arab rather than a purely Palestinian issue (Dorsey, 2021, February 3). The frequent demonstrations in countries like Bahrain, Jordan, and Morocco exemplify the social resentment against the normalization with Israel. Richard Cottam argued that another wave of strong popular uprising, as happened in the Arab Spring, could produce Arab unity, whether based on Arab nationalism or Islamic resurgence, or some combination of the two, that would threaten Israel and the Arab autocratic governments. Such a development would certainly represent a serious concern for American decision makers (1993, p. 62). U.S. support for Israel and the alignment with the autocratic Arab governments are consistent with the pursuance of the permanent national interest but risk the American reputation in the region. Arabs perceive the U.S. and Israel as the major threats they face. Opposition to the U.S. policy in the area is estimated at $75 \%$ of the region's population (Chomsky, 2016, pp. 46-47). U.S. support to the autocratic Arab governments is seen as blocking democratization and development to ensure control over the vital resources in the region.

The current study does not claim or pretend to examine all variables determining the Biden's Administration foreign policy towards the Middle East. Rather, this analysis focused on furthering an understanding of the dynamics of interactions that govern the Biden Administration's approach towards Middle Eastern contemporary issues encountering the democratic administration in Washington D.C. The paper constitutes a preliminary investigative assessment of the U.S. foreign policy in the first year of Joe Biden's presidency. It is intended to shed light on the continuing tension between U.S. permanent interests in the Middle East, and Biden's commitment to the 'American values' of supporting democratization and respect for human rights. How this tension will shape U.S. foreign policy towards the political development in the region will continue to be influenced by a myriad of volatile U.S. domestic factors and evolving international priorities.

\section{References}

Ahronhem, A. (2021, October 25). UAE Air Force Chief lands in Israel in first public visit. Retrieved from https://www.jpost.com/israel-news/uae-air-force-chief-lands-in-israel-in-first-public-visit-683048

Albright, D., \& Burkhard, S. (2021, September 22). Iran's Recent, Irreversible Nuclear Advances. Institute for Science and International Security. Retrieved from https://isis-online.org/isis-reports/detail/irans-recent-irreversible-nuclear-advances

Amirahmadi, H. (ed). (1993). The United States and the Middle East: A Search for New Perspective. Albany: State University of New York.

Arria, M. (2019, December 9). Biden hits Sanders on proposed policy, says conditioning military aid is "bizarre". Retrieved from https://mondoweiss.net/2019/12/biden-hits-sanders-on-proposed-israel-policy-says-conditioning-military-aid-is-biz arre/

Aruri, N. H. (1993). U.S. Policy towards the Arab- Israeli Conflict. In Amirahmadi, Hooshang (ed). The United States and the Middle East: A Search for New Perspective. Albany: State University of New York.

Avis, D. (2021, November 17). Israel and Jordan to Sign U.S.-Backed Water-for-Energy Pact. Retrieved from 
https://www.bloomberg.com/news/articles/2021-11-17/israel-and-jordan-to-sign-water-for-energy-pact-backed-by-u-s

AlAlkim, H. H. (1988). Al Syhywniah al Yahwudiah al Amerikyah wa Tathiraha 'Ala Syassat al Wilayat al Mutahidah al Kharijiah Tijah al 'Alim Al Arabi (The American Jewish Zionism \& Its Impacts on U.S. Policy Toward the Arab World) Shu'un Arabiah, No 56 (Dec.), 212-226.

AlAlkim, H. (1994). The GCC States in an Unstable World. London: Saqi Books.

AlAlkim, H. H. (2011). Dynamics of Arab Foreign Policy-Making in the Twenty First Century: Domestic Constraints \& External Challenges. London: Saqi Books.

AlAlkim, H. (2021). U.S. President Joe Biden's Foreign Policy towards the Gulf. Open Journal of Political Science, 11(3), 378-401. Retrieved from https://www.scirp.org/journal/paperinformation.aspx?paperid=109701

Alghafli, A. (2019). Societal Conflict Defies Peace Diplomacy: Evidence from the Palestinian-Israeli Conflict. Academic Journal of Interdisciplinary Studies, 8(1), 95-107. $\quad$ Retrieved from https://www.richtmann.org/journal/index.php/ajis/article/view/10414

Al-Kurwy, M., \& Abbas, F. (2011). Mauritanian- Israeli relations: From normalizations to freeze to suspension. Contemporary Arab Affairs, 4(1), 30-50. Retrieved from https://www.jstor.org/stable/48599738.

AlShamsi, M. J. (2011). Islam and Political Reform in Saudi Arabia: The quest for political change and reform. Oxford shire: Routledge.

Barber, J., \& Smith, M. (eds). (1974). The Nature Of Foreign Policy: A Reader. Edinburgh: Holmes McDougall.

Badi, E. (2020, April 21). Russia Isn't the Only One Getting Its Hands Dirty in Libya. Retrieved from https://foreignpolicy.com/2020/04/21/libyan-civil-war-france-uae-khalifa-haftar/

Bard, M. (2021). The UN Relationship with Israel. Retrieved from https://www.jewishvirtuallibrary.org/the-u-n-israel-relationship

Baroud, R. (2020, December 28). Untold Story of U.S. aid to Israel. Retrieved from https://www.arabnews.com/node/1784061

Bearak, M., \& Mohieddin, N. (2020, December 4). U.S. lifts Sudan's designation as a state sponsor of terrorism. Retrieved from

https://www.washingtonpost.com/world/africa/sudan-remove-state-terror-list/2020/12/14/7f119482-3d10-11eb-aad 9-8959227280c4_story.html

Ben-David, R. (2021, October 20). Israel, UAE to launch joint space projects, including Beresheet 2 Moon mission. Retrieved from

https://www.timesofisrael.com/israel-uae-to-launch-joint-space-projects-including-beresheet-2-moon-mission/

Berman, L. (2021, October 19). Bennett meets UAE, Bahrain envoys, is invited to Abu Dhabi for state visit. Retrieved from https://www.timesofisrael.com/bennett-meets-uae-bahrain-envoys-is-invited-to-abu-dhabi-for-state-visit/

Bertrand, N., \& Seligman, L. (2021, February 22). Biden's deprioritizes the Middle East. Retrieved from https://www.politico.com/news/2021/02/22/biden-middle-east-foreign-policy-470589

Borger, J. L. (2021, November 19). Work on 'Chinese military base' in UAE abandoned after US intervenes - report. Retrieved from

https://www.theguardian.com/world/2021/nov/19/chinese-military-base-uae-construction-abandoned-us-intelligenc e-report

Brecher, M. (1974). Krishna Menon's View of the World. In Barber, James and Smith Michael (eds). The Nature of Foreign Policy: A Reader. Edinburgh: Holmes McDougall.

Carlson, J. (2021). Nuclear Verification in a Middle East WMD Free Zone: Lesson from Past verification cases and Other Precedents. Geneva: UNIDIR. Retrieved from https://www.unidir.org

Cafiero, G. (2020, September 25). The African nation could be the next to normalize ties with Israel. Retrieved from https://www.trtworld.com/opinion/this-african-nation-could-be-the-next-to-normalise-ties-with-israel-40050

Chomsky, Noam. (2016). Who Rules the World? New York: Metropolitan Books.

Cohen, Z. (2021, December 23). CNN Exclusive: US intel and satellite images show Saudi Arabia is now building its own ballistic missiles with help of China. Retrieved from https://edition.cnn.com/2021/12/23/politics/saudi-ballistic-missiles-china/index.html

Congressional Research Service (CRS). (2020, November 23). Arms Sales in the Middle East: Trends and analytical 
Perspectives for U.S. Policy. Retrieved from https://fas.org/sgp/crs/mideast/R44984.pdf

Congressional Research Service (CRS). (2020, October 26). Israel's Qualitative Military Edge and possible U.S. Arms Sales to the United Arab Emirates, R46580. Retrieved from https://crsreports.congress.gov/product/pdf/R/R46580

Cooper, H. (2021, November 20). U.S. Tries to Convince Arab Allies It Isn't Abandoning Them. Retrieved from https://www.nytimes.com/2021/11/20/us/politics/us-middle-east.html

Cottam, R. (1993). U.S. Policy in the Middle East. In Amirahmadi, Hooshang (ed). The United States and the Middle East: A Search for New Perspective. Albany: State University of New York.

Crawford, N. C. (2019). United States Budgetary Costs and Obligations of Post-9/11 Wars through FY 2020: \$6.4 Trillion, A Cost of War Research Series. Watson Institute, Brown University, November 13.

Crowley, M. (2021, February 4). Biden Announces the End of U.S. Support to Saudi War in Yemen. The New York Times. Retrieved from https://www.nytimes.com/2021/02/04/us/biden-yemen-saudi-arabia.html

David H. (2016, July 29). UAE" funneled Money to Turkish Coup Plotters". Retrieved from https:/www.middleeasteye.net/fr/news/execlusive-uae-funnelled-money-turkish-coup-plotters-21441671

Dearden, L. (2014, August 27). Israel-Gaza conflict: 50-day war by numbers. Retrieved from https://www.independent.co.uk/news/world/middle-east/israel-gaza-conflict-50-day-war-numbers-9693310.html

Debre, I. (2021, April 30). Counting the Cost of America's 20-year war in Afghanistan. Retrieved from https://apnews.com/article/asia-pacific-afghanistan-middle-east-business-5e850e5149ea0a3907cac2f282878dd5

Dorsey, J. M. (2020, September 10). UAE Recognition of Israel Dents Emirate Religious Soft Power. Retrieved from https://www.mideastsoccer.blogspot.com/2020/09/uae-recognition-of-israel-dents-emirati.html

Dorsey, J. M. (2021, February 3). Concentration Camp Guides, the Far Right, and Islam: Europe Frays at the Edges. Retrieved from https://www.soundcloud.com/user-153425019/concentration-camp-guides-the-far-right-and-islam

Dorsey, J. M. (2021, Oct. 4). Concern about Iran prompts Israel to weigh acknowledgement of its own nuclear weapons. Retrieved from https://mideastsoccer.blogspot.com/2021/10/concern-about-iran-prompts-israel-to.html

Dorsey, J. M. (2021, November 2). Sudan and the UAE: Pulling Sudanese Strings. Retrieved from https://mideastsoccer.blogspot.com/2021/11/sudan-and-uae-pulling-sudanese-strings.html

Editors, History. (2021, April 27). Suez Crisis. Retrieved from https://www.history.com/topics/cold-war/suez-crisis.

Eberhart, D. (2021, August 14). An Energy and Political Crisis of Biden's Own Making. Retrieved from https://www.forbes.com/sites/daneberhart/2021/08/14/an-energy-and-political-crisis-of-bidens-own-making/?sh=6f $9163 \mathrm{e} 93412$

El Yaakoubi, A. (2019, May 2). Haftar's ally UAE says 'extremist militias' control Libyan capital. Retrieved from https://www.reuters.com/article/us-libya-security-emirates-idU.S.KCN1S80AO

El- Yaakoubi, A., Rashad, M., \& Barbuscia, D. (2021, July 5). Saudi Arabia Amends Imports Rules from Gulf in Challenge To UAE. Retrieved from https://www.reuters.com/world/middle-east/saudi-arabia-amends-import-rules-gulf-challenge-uae-2021-07-05/

Felton, G. (2018). The Host and the Parasite. FL: Money Tree Publishing.

Finnegan, C. (2020, December 12). Trump admin offered \$700M to 9/11 victims to save Sudan deal. Retrieved from https://abcnews.go.com/Politics/trump-admin-offered-700m-911-victims-save-sudan/story?id=74672919

Frankel, J. (1969). International Politics. United Kingdom: The Penguin.

Friedman, T. L. (2021, October. 26). Biden and Mother Nature Have Reshaped the Middle East. Retrieved from https://www.nytimes.com/2021/10/26/opinion/middle-east-climate-change.html

Gambrell, John (2021, January 16). US Calls Bahrain, UAE, 'Major Security Partners', Retrieved from https://www.usnews.com/news/world/articles/2021-01-16/us-calls-bahrain-uae-major-security-partners.

Goldenberg, I. (2021, June 21). Biden Can Keep the Two- State Solution Alive. Retrieved from https://www.foreignaffairs.com/articles/middle-east/2021-06-21/biden-can-keep-two-state-solution-alive

Gonen, Y. (2021, September 3). Israel Foreign Trade. Retrieved from https://www.trtworld.com/magazine/israel-s-trade-with-uae-and-other-arab-states-surged-by-234-percent-in-202149977

Gross, J. A. (2021, October 25). In landmark visit, UAE air chief in Israel to observe 'Blue Flag'exercise. Retrieved from 
https://www.timesofisrael.com/in-landmark-visit-uae-air-chief-in-israel-to-observe-blue-flag-exercise/

Harkov, L. (2021, October 21). Is the U.S. Consulate in Jerusalem for Palestinians a real issue? Retrieved from https://www.jpost.com/arab-israeli-conflict/is-the-us-consulate-in-jerusalem-for-palestinians-a-real-issue-682780

Harris, B. (2020, June 4). Intel: U.S. warns Middle Eastern partners against Chinese investment. Retrieved from https://www.al-monitor.com/originals/2020/06/schenker-china-uae-israel-lebanon-coronavirus-covid19.html

Readmore: https://www.al-monitor.com/originals/2020/06/schenker-china-uae-israel-lebanon-coronavirus-covid19.html \#ixzz78iKWnEPn

Hendawi, H. (2021, May 21). Biden calls Egypt's El Sisi for first time to discuss Palestine-Israel crisis. Retrieved from https://www.thenationalnews.com/mena/egypt/biden-calls-egypt-s-el-sisi-for-first-time-to-discuss-palestine-israelcrisis-1.1226799

Holmes, O. (2020, November 23). Netanyahu holds secret meeting with Saudi crown prince. Retrieved from https://www.theguardian.com/world/2020/nov/23/benjamin-netanyahu-secret-meeting-saudi-crown-prince-moham med-bin-salman

Hope, B., \& Scheck, J. (2020). Blood \& Oil: MBS’s Ruthless Quest for Global Power. New York: Hachette Books.

Intelligence Online, Issue 869. (2021, January 27). Israel's integration in CENTCOM set to change intelligence-sharing. Retrieved from https://www.intelligenceonline.com/grey-areas/2021/01/27/israel-s-integration-in-centcom-set-to-change-intelligen ce-sharing,109638042-gra

Jakes, L., Kershner, I., Alami, A., \& Halbfinger, D. (2020, December 10). Morocco Joins List of Arab Nations to Begin Normalizing Relations with Israel. Retrieved from https://www.nytimes.com/2020/12/10/world/middleeast/israel-morocco-trump.html

Jewish Virtual Library. (2018, June 1). UN Security Council: U.S. Vetoes of Resolutions critical to Israel 1972- Present. Retrieved from https://www.jewishvirtuallibrary.org/u-s-vetoes-of-un-security-council-resolutions-critical-to-israel

Kingsley, P. (2021, November 4). Israel Advances Plan for New Settlement Homes, in First for Bennett Era. Retrieved from https://www.nytimes.com/2021/10/27/world/middleeast/israel-settlements-west-bank.html

Lewis, S., \& Parmuk, H. (2021, October 27). Biden administration issues sharpest rebuke yet to Israel over settlements. Retrieved from

https://www.reuters.com/world/middle-east/us-voices-opposition-israels-plans-new-west-bank-settlement-homes-2 021-10-26/

Lilienthal, A. M. (1978). The Zionist Connection: What Price Peace. NY: Dodd, Mead \& Company.

Lis, Jonathon. (2021, September 1). Bennett Rejects Peace Process with Abbas, Focuses on Palestinians' Practical Needs. Retrieved from

https://www.haaretz.com/israel-news/.premium-bennett-closes-door-on-peace-process-focuses-on-palestinians-pra ctical-needs-1.10174014

Lubold, G., \& Strobel, W. P. (2021, November 19). Secret Chinese Port Project in Persian Gulf Rattles US Relations with UAE. Retrieved from https://www.wsj.com/articles/us-china-uae-military-11637274224

Magid, J. (2021, January 29). Biden breaks from predecessors by taking it slow on Israeli- Palestinian peace. Retrieved from https://www.timesofisrael.com/biden-breaks-from-predecessors-by-taking-it-slow-on-israeli-palestinian-peace/

Magid, J. (2021, Feb. 2). UAE ambassador: 'Abraham Accords were about preventing annexation'. Retrieved from https://www.timesofisrael.com/uae-ambassador-abraham-accords-were-about-preventing-annexation/

Mearsheimer, J., \& Walt, S. (2008). The Israel Lobby and U.S. Foreign Policy. London: Penguin Books.

Mezran, K., \& Varvelli, A. (eds.) (2019). The Mina Region: A Greater Power Competition. Milano: LedozioniLedi Publishing (published by ISPI \& Atlantic Council).

Millar, T. B. (1969). On Writing About Foreign Policy. In James Rosenau. International Politics and Foreign Policy. NY: The Free Press.

Nereim, V. (2020, December 6). Senior Saudi Prince Blasts Israel at Security Conference. Retrieved from https://www.bloomberg.com/news/articles/2020-12-06/senior-saudi-prince-blasts-israel-at-security-conference

Nye, J. S. (2020). Do Morals Matter? Presidents and Foreign Policy from FDR to Trump. New York: Oxford Press. 
Obama, B. (2020). A Promised Land. Crown.

O’Brien, L. (1986). American Jewish Organization \& Israel. VA: Progressive Litho., Inc.

OPEC Annual Statistical Bulletin. (2020). Retrieved from https://www.opec.org/ opec_web/static_files_project/ media/downloads/publications/ASB_2020.pdf

Pack, J. (2020, August 21). The Israel-UAE Deal Won't Bring Peace, but It Will Prolong the War in Libya. Retrieved from https://foreignpolicy.com/2020/08/21/the-israel-uae-deal-wont-bring-peace-but-it-will-prolong-the-war-in-libya/

Parsi, T. (2021). Toward an Inclusive Security Arrangement in the Persian Gulf. Quincy Brief No. 7, Quincy Institute for Responsible Statecraft.

Rabinovitch, A., \& Cohen, T. (2020, October 20). Israeli pipeline company signs deal to bring UAE oil to Europe. Retrieved from https://www.reuters.com/article/emirates-israel-pipeline-int-idU.S.KBN275152

Ravid. B. (2021, May 22). 11 days, 8 calls and a ceasefire: Inside Biden's response to the Gaza crisis. Retrieved from https://www.axios.com/gaza-crisis-israel-biden-response-3119a844-357a-4f5f-ba7e-3c497475893a.html

Rihawi, J. (1996, April 2). Peres Signs Economic Accord IN Qatar. Retrieved from https://www.upi.com/Archives/1996/04/02/Peres-signs-economic-accord-in-Qatar/6487828421200/

Robinson, T. W. (1969). National Interest. in Rosenau, James N. (ed). International Politics and Foreign Policy. NY: The Free Press.

Rosenau, J. N. (ed.) (1969). International Politics and Foreign Policy. NY: The Free Press.

Rosenau, J. N. (ed). (1969). Linkage Politics. NY: The Free Press.

Ruger, W. (2020, August 6). NEW POLL: 3 in 4 Americans want troops home from Afghanistan, Iraq; favor less defense spending, less military engagement abroad. Retrieved from https://charleskochinstitute.org/news/new-poll-3-in-4-americans-want-troops-home-from-afghanistan-iraq-favor-le ss-defense-spending-less-military-engagement-abroad/

Rubin, S. (2020). Convicted spy Jonathan Pollard arrives in Israel in latest Trump parting gift. Retrieved from https://www.washingtonpost.com/world/middle_east/pollard-israel-spy-trump-netanyahu/2020/12/30/76a52f38-4a 59-11eb-97b6-4eb9f72ff46b_story.html

Sagir, D. (2021, Sept. 30). Retrieved from https://www.haaretz.com/israel-news/. premium. HIGHLIGHT. MAGAZINE-then-sadat-told-the-israeli-minister-you-have-nuclear-arms-haven-t-you-heard-1.10255246?utm_sour ce=mailchimp \&utm_medium $=$ content $\& u t m \_$campaign $=$weekend $\& u t m \_$content $=90 \mathrm{ef} 502 \mathrm{a} 9 \mathrm{~b}$

Satloff, R. (2021, November 19). Sheikh Mohamed bin Zayed receives award for Israel deal. Retrieved from https://www.zawya.com/mena/en/economy/story/Sheikh_Mohamed_bin_Zayed_receives_award_for_Israel_deal-S NG_262507155/

Shesgreen, D. (2021, May 19). Biden tells Netanyahu he expects 'a significant de-escalation today' with path toward cease-fire. Retrieved from

https://www.usatoday.com/story/news/politics/2021/05/19/biden-says-he-expects-significant-de-escalation-today-g aza/5162735001/

Sink, J. (2021, January 29). Biden Adviser Warns of "Escalating Nuclear Crisis" with Iran. Bloomberg. Retrieved from https://www.bloomberg.com/news/articles/2021-01-29/biden-adviser-warns-of-escalati ng-nuclear-crisis-with-iran

Slackman, M. (2009, January 11). Crisis Imperils 2- State Plan, Shifting a Balance. Retrieved from https://www.nytimes.com/2009/01/12/world/middleeast/12egypt.html

Smith, G. A. (2021, September 15). More White Americans adopted than shed evangelical label during Trump presidency, especially his supporters. Retrieved from

https://www.pewresearch.org/fact-tank/2021/09/15/more-white-americans-adopted-than-shed-evangelical-label-dur ing-trump-presidency-especially-his-supporters/

Smith, M. et el.(eds). (1985). Perspectives on World Politics. London: Croom Helm.

Steinberg, G.. (2020, July 8). Regional Power United Arab Emirates: Abu Dhabi is no longer Saudi Arabia's Junior Partner. SWP Research Paper 2020/RP 10, 08.07.2020, 35 Seiten. Retrieved from https://www.swp-berlin.org/10.18449/2020RP10/

Stockholm International Peace Research Institute (SIPRI) (2020, March 9). U.S.A and France Dramatically Increase 
Major Arms Exports; Saudi Arabia Is Largest Arms Importer. SIPRI. Retrieved from https://www.sipri.org/media/press-release/2020/usa-and-france-dramatically-increasemajor-arms-exports-saudi-arabia-1 argest-arms-importer-says

Stork, J. (1993). U.S. Policy and the Palestinian Question. In Amirahmadi, H. (Ed.), The United States and the Middle East: A Search for New Perspective. Albany: State University of New York.

Swan, M. (2021, September 23). Israeli police to be permanently based in UAE in historic first. Retrieved from https://www.telegraph.co.uk/world-news/2021/09/23/israeli-police-permanently-based-uae-historic-first/

Taha, R. (2021, August 26). Pentagon highlights U.S. support for replenishing Israel's Iron Dome defense system. Retrieved from

https://www.english.alarabiya.net/News/middle-east/2021/08/26/Pentagon-highlights-U.S.-support-for-replenishin g-Israel-s-Iron-Dome-defense-system

Woodward, B. (2020). Rage. New York: Simon \& Schuster.

Worden, R. (2018. March 5). The UAE Still Supports al-Shabaab through Somalia's illicit Charcoal trade. Retrieved from https://www.english.alaraby.co.UK/opinion/uqe/uae-still-supports-al-shabaab-through-somalia's-illicit-charcoal-tra de.

Yacub, Salem. (2008April 22). Scuttle Diplomacy: Henry Kissinger and Arab-Israeli Peacemaking. Retrieved from https://www.wilsoncenter.org/event/scuttle-diplomacy-henry-kissinger-and-arab-israeli-peacemaking

Zengerle, P., Pamuk, H., \& Spetalnick, M. (2021, May 22). Analysis: Gaza conflict forces reordering of Biden's policy priorities. Retrieved from

https://www.reuters.com/world/middle-east/gaza-conflict-forces-reordering-bidens-policy-priorities-2021-05-21/

\section{Endnotes} i The origin, the size and the objective behind the name of the Middle East is debatable. For the purpose of this paper, it is
a transcontinental region in Afro-Eurasia which includes Western Asia and North Africa, Turkey and Iran
ii The U.S.- UK nuclear submarines deal with Australia is an example of Biden's administration policy to contain the
Chinese threat in South Asia. The announcement on September $24^{\text {th }}$ of the Washington Declaration forming a quadrant
military alliance consisting of the U.S., India, Japan and Australia to maintain peace and security in the Indian and Pacific
oceans is another manifestation of the U.S. new policy to deter Chinese threat in the south Asia region.

iii Foreign policy is presumably something less than the sum of all policies which have an effect upon national government's relations with other national governments. Millar, T. B. "On Writing About Foreign Policy” in Rosenau, James N. (1969). International Politics and Foreign Policy. NY: The Free Press, p. 57.

iv National interest, according to Morgenthau, contains two elements: the logically required or necessary as nation survival protecting their physical, political, and cultural identity against encroachments by other nations, and one that is variable determined by circumstances. Morgenthau, Hans J. "Another 'Great Debate': The National Interest of the U.S.", in Smith, Michael et al., (eds). (1985). Perspectives on World Politics. London: Croom Helm, p.47.

${ }^{v}$ Diplomacy is the technique to accommodate conflicting interests. It attempts to reconcile one's own national interests with those of other actors. Robinson, Thomas W. National Interest. in Rosenau, James N., Op.cit., p. 188.

${ }^{v i}$ It looks that there is a light at the end of the tunnel, the Libya predicament seems to be approaching a peaceful end with the UN success to engage the warring factions and elect new government.

vii For more details see AlAlkim, Hassan, “U.S. President Joe Biden's Foreign Policy towards the Gulf”, Open Journal of Political Science, Vol. 11 No. 3, 378-401.

${ }^{\text {viii }}$ https://www.aa.com.tr/en/africa/haftar-and-israel-from-animosity-to-alliance-/1924585

ix http://icfuae.org.uk/uae-in-the-media/israel-provided-haftar-weapons-uae-mediated

${ }^{\mathrm{x}}$ https://www.i24news.tv/en/news/international/1638003745-report-uae-operating-air-bridge-to-ethiopian-army

${ }^{\text {xi }}$ https://www.france24.com/en/live-news/20211012-israel-signs-deal-to-double-water-supply-to-jordan-1

xii https://www.iiss.org/events/2021/10/ecopeace

xiii Salim Yaqub cited several examples of Kissinger's duplicity during the course of his shuttle negotiations. The starkest contrast was in early May 1974 statements to the Israeli Prime Minister Golda Meir and the Saudi Arabian King Faisal. To 
Golda Meir on May 6, 1974: He said "It was almost unanimous in our group [i.e., U.S. negotiating team] that the Israelis should not be asked to give up Golan. That will not be a contentious issue between Israel and the United States." To King Faisal of Saudi Arabia on May 9, 1974: He revealed that "the United States supports no claim by Israel to the Golan Heights". For more details see Yacub, Salim. (2008, April 22). Scuttle Diplomacy: Henry Kissinger and Arab-Israeli Peacemaking. https://www.wilsoncenter.org/event/scuttle-diplomacy-henry-kissinger-and-arab-israeli peacemaking?gclid=Cj0KCQjwt6LBhDlARIsAIPRQcLhc70dwW827G6SgUm331r15ON9HZRqE4fQf7Bw4rJ8uwyJ1 AGDQQaAvrrEALw_wcB

${ }^{\text {xiv }}$ It includes Salman al-Awda, Nasir al-Umar and Safar al-Hawali who are all imprisoned for their activities in leading the Saudi Islamic Sahwa (revivalism) and voicing their support for the Arab spring.

${ }^{x v}$ Saudi Arabia and the UAE have entered a new phase of competition, most evident in their face-off about a proposed OPEC+ deal to raise oil output.

${ }^{x v i}$ It is alleged that Anwar Sadat and Hafez Assad, during the October 1973 war, understood Israel's nuclear capabilities, but new that their own goals would not to trigger an unconventional response. Sadat told the Israeli Deputy Prime Minister, Yigal Yadin, during his first visit to Israel in 1977 when asked why the Egyptian army had not moved into Sinai during the 1973 war by saying: "You have nuclear arms. Haven’t you heard?” (Sagir, Dan, 2021, September 30).

${ }^{\text {xvii }}$ https://mideastsoccer.blogspot.com/2020/08

\section{Copyrights}

Copyright for this article is retained by the author(s), with first publication rights granted to the journal.

This is an open-access article distributed under the terms and conditions of the Creative Commons Attribution license which permits unrestricted use, distribution, and reproduction in any medium, provided the original work is properly cited. 